\title{
A single nucleotide polymorphism in $B C L-2$ gene determines the risk of urinary bladder cancer
}

\author{
Saranjeet Kaur \\ Department of Zoology, Panjab University, Chandigarh, India
}

\begin{abstract}
The aim of the study was to investigate genetic polymorphism in apoptotic gene, BCL-2 (C938A), and the risk of bladder cancer through a hospital-based case-control study. This retrospective analysis consisted of 270 cases of bladder cancer and 252 controls. The BCL-2 938 AA genotype showed a decreased risk of bladder cancer among smokers $(O R=0.40,95 \% C I=0.19-0.85)$, hence, showing a protective effect. The BCL-2 938 AA genotype also showed a significant decreased risk among vegetarians $(O R=0.39,95 \% C I=0.14-1.06)$ for bladder cancer. No significant associations were observed for this polymorphism among any of the stages or grades of carcinoma of urinary bladder.
\end{abstract}

Keywords: Bladder Cancer, BCL-2, Polymorphism, SNP, Apoptosis

\section{Introduction}

The incidence of bladder cancer in India appears to be increasing (Kekre, 2008). It is also one of the leading causes of deaths in India (Vaish et al., 2005). As far as genotoxicity is concerned, there is a highly significant involvement of environmental carcinogens in increasing the risk of carcinoma of urinary bladder. Some of these carcinogens are derived from occupational exposures, cigarette smoking, inflammatory conditions and schistosomal infections. Generally, such factors are enough to cause genetic changes that may irreversibly lead to conversion of a normal urothelial cell to one with the malignant phenotype (Jung and Messing, 2000).

DNA repair, genomic instability and apoptosis, the three phenomena being intimately linked, make the research on apoptosis imperative in the domain of cancer. The research carried out upon SNPs in apoptosis in relation to cancer is likely to represent tip of the iceberg.

Apoptosis can be initiated by two different pathways: (1) the extrinsic pathway, which can be triggered by ligation of death receptors and subsequent caspase- 8 activation; or (2) the intrinsic pathway, which is initiated by cellular stress followed by activation of caspase-9 (Ghavami et al., 2009). Each of these pathways converges to a common execution phase of apoptosis that requires proteolytic activation of caspase- $3 \mathrm{and} /$ or -7 form their inactive zymogens (Ghavami et al., 2009).

The BCL-2 protein family lies at the heart of the intrinsic pathway to apoptosis, the interactions between them being central to determining if a cell lives or dies (Youle and Strasser, 2008). These family members share regions of primary sequence and structural similarity and are grouped into three subfamilies based on the number of BH (BCL-2 Homology) domains they share. The involvement of BCL-2 protein family in regulating apoptosis leads to an understanding of the molecular web that controls tumour cell death and survival (Cotter, 2009).

$\mathrm{BCl}-2$ inhibits apoptosis through several mechanisms: heterodimerization with pro-apoptotic members of the BCL-2 family, such as BAX and BAK, and the formation of channels that stabilize the mitochondrial membrane, preventing the release of cytochrome $\mathrm{c}$ and second mitochondria-derived activator of caspases (Van Loo et al., 2002). Apart from this, it induces cell cycle arrest in $\mathrm{G}^{\circ}$ as well (Cory and Adams, 2002).

The $B C L-2$ gene is located on chromosome 18q21.3. It consists of three exons and two promoters, P1 and P2. The second promoter, P2, is located 1400-bp upstream of the translation inititation site and decreases the activity of the P1 promoter, thus, acting as a negative regulatory element (Seto et al., 1988; Young and Korsmeyer, 1993). Park et al. (2004) identified 6 SNPs in the BCL-2 gene by direct sequencing of DNA samples from a white population. There is only one reported single nucleotide polymorphism in the inhibitory P2 promoter region, which has been validated by the published allele frequency and genotype data, that locates at nucleotide position -938 (rs2279115) in the P2 promoter region (Kidd et al., 2006). The P53 has been shown to downregulate $B C L-2$ (Miyashita et al., 1994a) via binding to a negative regulatory element outside of the $B C L-2$ gene promoter (Miyashita et al., 1994b).

The current study is the first one showing an association between carcinoma of urinary bladder and $B C L-2$ polymorphism. No studies pertaining to the same are available in the literature. 


\subsection{Study design and study subjects}

\section{Materials And Methods}

This retrospective case-control study comprised 270 histopathologically proven cases of urinary bladder cancer and 252 cancer-free controls. Peripheral blood samples from patients with urinary bladder cancer, treated at Advanced Urology Centre (AUC) of the Post Graduate Institute of Medical Education and Research (PGIMER), Chandigarh, were collected during routine investigations. The ethical clearance for the present study was obtained from the Institute's Ethics Committee. Cases having HIV, allergies and other cancers, or patients having received chemotherapy were excluded. Informed consents were obtained from all the participants. Data with respect to their age, sex, smoking status, alcohol consumption, occupational status, area inhabited and eating habits were recorded. In patients with bladder tumor, the stage and grade of the tumor were noted.

\subsection{Genotype analysis}

Peripheral blood samples $(2-4 \mathrm{ml})$ were collected from cases and controls in EDTA-coated vials. Genomic DNA was subsequently extracted from peripheral blood lymphocytes by the standard phenolchloroform method. The $B C L-2$ C-938A polymorphism was then determined by PCR-RFLP assay as per the conditions given in Table I (Fig. I). A mismatch was introduced near the 3' end of each of the primers, close to the mutation of interest, to create an artificial restriction site in the PCR product (PIRA-PCR - Primer Introduced Restriction Analysis-PCR) (Ke et al., 2001). Independent repetition of genotyping in randomly selected samples produced the same results and hence, proved concordance.

\subsection{Statistical analysis}

The power calculations were conducted at $80 \%$ with a significance level of 0.05 . The sample size used for the present study was adequate. The data showed normal distribution on applying one-sample KolmogorovSmirnov $\mathrm{Z}$ test when age was taken as the test variable. The data were age-matched, as confirmed by T-test. The odds ratios (ORs) and 95\% confidence intervals (CIs) were obtained using $\chi^{2}$ test and Fisher-Exact test for categorical variables. The odds ratios were calculated without adjustment for potential confounders, i.e., sex, area, job status, smoking, alcohol consumption and diet. Based on previous studies, occupations related to auto mechanics (Manju et al., 2009), agricultural production, livestock and animal specialities; electrical assembly, installation and repair; and health services (Cassidy et al., 2009); printing industry, transportation equipment industry, electrical/gas/sanitary services (Samanic et al., 2008); were altogether taken under the category of high-risk occupations and the rest under low-risk occupations.

To achieve an adequate sample size with power of study at $80 \%$, the various tumor stages were clubbed together and merged into two groups, i.e., superficial $(\mathrm{Ta}+\mathrm{T} 1)$ and muscle-invasive $(\mathrm{T} 2+\mathrm{T} 3+\mathrm{T} 4)$. Both additive and dominant modes of inheritance were considered. The $p$-values were two-sided. Values less than 0.05 were considered as significant. All analyses were performed using SPSS, version 15.0 and Epi Info, version 3.4.3.

\section{Results}

The distribution of the genotype and allele frequencies of $B C L-2 C-938 A$ polymorphism among cases and controls is summarized in Table II. The allele frequencies were $77.96 \%$ for allele $C$ and $22.04 \%$ for allele $A$ in the cases. In the control group, the allele frequencies for allele $C$ were $74.6 \%$ and for allele $A$ were $25.4 \%$. No significant differences were observed in the genotype frequencies with regard to bladder cancer for the $B C L-2$ polymorphism on considering either of the models (dominant/additive).

The interaction of $B C L-2 \quad C-938 A$ polymorphism with various environmental factors has been summarized in Table III. The $A A$ genotype showed a decreased risk of bladder cancer among smokers $(\mathrm{OR}=$ $0.40,95 \% \mathrm{CI}=0.19-0.85$ ), hence, showing a protective effect. The $A A$ genotype also showed a significant decreased risk among vegetarians $(\mathrm{OR}=0.39,95 \% \mathrm{CI}=0.14-1.06)$ for bladder cancer. The interaction of $B C L$ 2 C-938A polymorphism with each histological subcategory is summarized in Table IV. No significant associations were observed for this polymorphism among any of the stages or grades.

\section{Discussion}

No significant differences were observed in the frequencies of $B C L-2$ genotypes in bladder cancer cases and controls. However, presence of $B C L-2$ is proposed to confer a growth advantage to tumour cells (Atug et al., 1998; Asci et al., 2001). BCL-2 overexpression is rare in transitional cell carcinoma (TCC) of the bladder (Kirsh et al., 1998). It is well known that depending on the tumour type, expression of $B C L-2$ is related to different biological behaviours. BCL-2 expression may either mediate $\mathrm{G}_{\mathrm{o}}$ arrest of tumour cells (Cory and Adams, 2002) leading to a decreased tumour growth or act antiapoptotic, thus promoting tumour growth and a less favourable outcome of cancer patients (Cory and Adams, 2002; Zinkel et al., 2006). In contrast, it has also 
been shown that under certain conditions apoptosis may be triggered by $B C L-2$ expression itself (Hanson et al., 2008). The differential tumour behaviour, however, may be mediated by other biological processes such as angiogenesis and immune response, which have also been shown to be functionally modulated by $B C L-2$ (Kumar et al., 2008).

Increased $B C L-2$ expression is associated with unfavourable outcome in B-cell chronic lymphocytic leukemia (CLL) and prostate cancer (Keshgegian et al., 1998; Faderl et al., 2002), whereas its expression is related to increased survival in colorectal and breast carcinoma (Ofner et al., 1995; Zhang et al., 1998). Results were conflicting, in head and neck cancer patients, but the majority of studies had shown increased $B C L-2$ expression to be associated with a more favourable outcome (Wilson et al., 1996; Homma et al., 1999; Pena et al., 1999). Moreover, $B C L-2$ expression is not uniformly distributed among head and neck cancer subsites. According to tumour site, $B C L-2$ expression varies from 5 to $35 \%$; its highest expression rate is found in oropharyngeal carcinoma (Stoll et al., 2000). The expression of $B C L-2$ was increased in most colorectal adenocarcinomas compared with normal mucosal tissue (Hague et al., 1994; Bronner et al., 1995). Sinicrope et al. (1995) showed spontaneous apoptosis to be reduced in colorectal carcinomas that had high $B C L-2$ expression compared with tumours with low or absent $B C L-2$ expression. The mechanisms behind increased or decreased rates of expression are not clear at all.

The chronic lymphocytic leukemia (CLL) cells have been reported to express high levels of $B C L-2$. Expression generally appeared to be equivalent to or to exceed that in normal peripheral blood lymphocytes, or even that in cells containing the $\mathrm{t}(14: 18)$ translocation (Hanada et al., 1993). The mechanisms that mediate $B C L-2$ expression in CLL are not clear yet. CLL cells can have increased $B C L-2 / B A X$ ratios (favouring cell survival) compared to normal controls in at least some individuals (Pepper et al., 1997; Saxena et al., 2004). Individual variation in the expression of $B C L-2 / B A X$ ratios are associated with increased sensitivity to cytotoxic drugs in vitro and improved responses to chemotherapy in patients (Thomas et al., 1996; Pepper et al., 1997; Saxena et al., 2004).

Quantification of the anti-apoptotic protein BCL-2 in patients undergoing neoadjuvant chemotherapy plus radiotherapy for advanced bladder cancer may identify patients who might benefit from neoadjuvant chemotherapy (Cooke et al., 2000). The BCL-2 protein inhibits apoptosis and is overexpressed by many tumours including breast (Hellemans et al., 1995), colon (Bronner et al., 1995), prostate (Krajewska et al., 1996) and tumours of the head and neck (Gallo et al., 1999). By virtue of its biological activity, it may be associated with a poor prognosis, with resistance to current treatment modalities including radiotherapy, for example, in cervical (Harima et al., 1998) and prostate (Apakama et al., 1996) cancers. The information on the role played by $B C L-2$ in transitional cell carcinoma (TCC) of the bladder is quite limited and conflicting, with some studies showing an association with a lower tumour grade (King et al., 1996) and less aggressive phenotype (Shiina et al., 1996). Others have shown the reverse, with expression being greater in higher-stage and higher-grade tumours, thereby, resulting in increased frequency of disease recurrence and higher disease progression rates, leading to shortened survival (Pollack et al., 1997; Kong et al., 1998; Ye et al., 1998). It is quite possible that these conflicting results have been because of different interactions between the various treatment modalities and apoptotic pathways.

The -938C $>A$ SNP of $B C L-2$ gene is located within 100 bases from the TP-53 responsive element in the $B C L-2$ promoter region (Chen et al., 2007). The BCL-2 -938C allele codes for a putative binding site for Sp1 , which plays an important role in the transcription of numerous genes and which is abolished in the presence of $B C L-2-938 A$ allele (Nuckel et al., 2007). The $A$ variant genotypes at the position -938 of the $B C L-2$ promoter may render a better interaction with TP53, leading to a decrease in the $B C L-2$ expression, an up-regulated programmed cell death or reduced longevity of the transformed cells, and thus a subsequent decrease in the risk of cancer (Chen et al., 2007). In the present study, the allele $C$ was more in cases whereas, allele $A$ was more in controls, which runs parallel to the above justification. No significant differences were observed in the genotype frequencies with regard to bladder cancer for the $B C L-2$ polymorphism on considering either of the models.

There is no study available pertaining to $B C L-2938 C / A$ polymorphism on bladder cancer. Earlier studies on $B C L-2$ polymorphism and risk of other cancers did not show any significant differences between cases and controls. As both genotype distributions and allele frequencies were not significantly different in patients and controls, there was no evidence for an association of $B C L-2938$ genotypes with an increased risk to develop CLL (Nuckel et al., 2007). Majid et al. (2008) also failed to confirm that the $-938 C>A$ polymorphism associates with BCL-2 protein levels and disease progression in CLL. Chen et al. (2007) analyzed the role of $B C L-2(-938 C>A)$ as risk factor for head and neck squamous cell carcinoma (HNSCC) in a large series of Caucasian patients. Risk analysis in the whole-study population revealed no significant differences between genotypes $(P=0.933)$. Even after liaisons of variant genotypes, no significant results were observed. Lehnerdt et al. (2009) analyzed the $-938 C>A$ polymorphism specifically in oropharyngeal squamous cell carcinoma (OSCC), the HNSCC subsite with the highest $B C L-2$ expression rate, as possible modulator of the clinical 
course. But, overall analysis of genotype distributions of cases and controls was not significantly associated with the risk for OSCC $(P=0.074)$. The results of present study are in accordance with these studies.

Kidd et al. (2006), with a relatively small sample size, investigated the role of this SNP in the etiology of prostate cancer and reported a decrease in prostate cancer risk. They found variant allele of $B C L-2-938 C>A$ to be associated with reduced risk of prostate cancer in Caucasians, possibly due to the elimination of an $\mathrm{Sp} 1$ binding site, a downregulation of $B C L-2$ mRNA transcript levels, and unregulated programmed cell death. It was consistent with what was found in another study conducted by Hu et al. (2008).

\subsection{Smoking}

Teni and colleagues (2002) have analyzed the expression of $B C L-2$ gene in chewing tobacco-induced oral cancers and oral lesions from India. Their study demonstrated frequent (43-56\%) over-expression of $B C L-2$ in the tobacco chewing associated oral cancers in Indians. In addition, aberrant $B C L-2$ expression was also demonstrated in a subset (16\%) of oral lesions, representing early events in oral tumourigenesis (Teni et al., 2002).

It is possible that nicotine may be regulating $B C L-2$ to stimulate cell survival. Mai et al. (2003) reported that nicotine can induce BCL-2 phosphorylation exclusively at the serine-70 site in association with prolonged survival of SCLC H82 cells expressing wild-type, but not the phosphorylation-deficient S70A mutant $B C L-2$ after treatment with chemotherapeutic agents (cisplatin or VP-16).

Nicotine induces activation of PKC $\alpha$ and the MAPKs ERK1 and ERK2, which are physiological BCL2 kinases. Furthermore, ET-18-OCH3, a phospholipase C (PLC) inhibitor, blocks nicotine-stimulated BCL-2 phosphorylation and promotes apoptosis, suggesting that PLC may be involved in nicotine activation of BCL-2 kinases (Mai et al., 2003). Thus, nicotine-induced cell survival results, at least in part, form a mechanism that involves BCL-2 phosphorylation.

A correlation between heavy cigarette smoking and increased expression of $B C L-2$ in patients with lung, head, or neck cancer suggests that $B C L-2$ may be a target of carcinogens found in tobacco smoke (Gallo $e t$ al., 1995).

It is possible that nicotine-induced upregulation of the anti-apoptotic activity of BCL-2 results from phosphorylation, because the post-translational modification potently enhances the stability of BCL-2 protein (Dimmeler et al., 1999; Deng et al., 2001). Phosphorylation of BCL-2 at $\operatorname{Ser}^{70}$ stabilizes its heterodimeric interaction with BAX (Deng et al., 2000), a pro-apoptotic molecule required for cell death (Wei et al., 2001). The data of Mai and colleagues (2003) supported and extended these findings, because nicotine stimulates not only $\mathrm{Ser}^{70}$ site BCL-2 phosphorylation but also BCL-2/BAX heterodimerization, a mechanism currently thought to block the death action of BAX (Oltvai et al., 1993). Since the $B C L-2$ polymorphism belongs to the promoter region of $B C L-2$, it is quite possible that it might be affecting the phosphorylation of BCL-2 at $\mathrm{Ser}^{70}$ site. As $B C L-2 A A$ genotype was found to be protective in smokers, it could be possible that the $A$ allele might be regulating the decrease in BCL-2 phosphorylation.

\subsection{Diet}

The $B C L-2 A A$ genotype had a protective effect among vegetarians. Many studies have been carried out particularly on $B C L-2$ expression. According to one study, a combination of genistein, quercetin and biochaninA was significantly more effective than individual compounds or their double combinations in decreasing $B C L$ 2 mRNA expression as well as protein levels in prostate cancer (Kumar et al., 2010). Quercetin, a flavonoid found in vegetarian diet, downregulated BCL-2 (Chang et al., 2005; Vijayababu et al., 2005). Sulforaphane, an isothiocyanate derived from cruciferous vegetables such as broccoli, decreased $B C L-2$ expression during apoptosis induction (Fimognari et al., 2003; Karmakar et al., 2006; Xu et al., 2006). Phenethyl isothiocyanate (PEITC) caused a decrease in the levels of $B C L-2$, which resulted in the release of cytochrome $\mathrm{c}$ in MCF-7 cells (breast cancer cell line) (Lee and Cho, 2008), and hence, promotion of apoptosis. This could be one of the reasons as to why $B C L-2 A A$ genotype had a protective effect among vegetarians. The vegetable consumption might be down-regulating $B C L-2$ and hence, preventing cancer.

\section{Conclusion}

Although of significant interest, further work is required to determine the frequency of these polymorphisms in larger cohorts of cancer patients and normal individuals, not only in bladder cancer but also in various other cancers, as the literature pertaining to $B C L-2$ polymorphism is very less. To evaluate whether genotyping of the $B C L-2$ polymorphism may offer the opportunity to identify responders and non-responders to $B C L-2$ targeted therapy, prospective clinical trials are necessary. 


\section{Acknowledgement}

This study was supported by Junior Research Fellowship (JRF) grant provided by Council of Scientific and Industrial Research (CSIR), Human Resource Development Group (HRDG), Library Avenue, Pusa, New Delhi - 110012, India. We are indebted to the staff of PGIMER, Chandigarh - 160012, India, for their close cooperation and important contributions.

\section{References}

[1] Vaish M, Mandhani A, Mittal RD, Mittal B. (2005). Microsatellite instability as prognostic marker in bladder tumors: a clinical significance. BMC Urol, 5: 2-8.

[2] Kekre NS. (2008). Bladder Cancer: Need for a standardized protocol of management. Indian J Urol, 24 (1): 1.

[3] Jung I, Messing E. (2000). Molecular mechanisms and pathways in bladder cancer development and progression. Cancer Control, 7 (4): $325-34$

[4] Ghavami S, Hashemi M, Ande SR, Yeganeh B, Xiao W, Eshraghi M, Bus CJ, Kadkhoda K, Wiechec E, Halayko AJ, Los M. (2009). Apoptosis and cancer: mutations within caspase genes. J Med Genet, 46 (8): 497-510.

[5] Youle RJ, Strasser A. (2008). The BCL-2 protein family: opposing activities that mediate cell death. Nat Rev Mol Cell Biol, 9 (1): 47-59.

[6] Cotter TG. (2009). Apoptosis and cancer: the genesis of a research field. Nat Rev Cancer, 9 (7): 501-7.

[7] Van Loo G, Saelens X, Matthijssens F, Schotte P, Beyaert R, Declercg W, Vandenabeele P. (2002). Caspases are not localized in mitochondria during life or death. Cell Death Differ, 9 (11): 1207-11.

[8] Cory S, Adams JM. (2002). The BCL-2 family: regulators of the cellular life-or-death switch. Nat Rev Cancer, 2 (9): 647-56.

[9] Seto M, Jaeger U, Hockett RD, Graninger W, Bennett S, Goldman P, Korsmeyer SJ. (1988). Alternative promoters and exons, somatic mutation and deregulation of the BCL-2-Ig fusion gene in lymphoma. EMBO J, 7 (1): 123-31.

[10] Young RL, Korsmeyer SJ. (1993). A negative regulatory element in the BCL-2 5'-untranslated region inhibits expression from an upstream promoter. Mol Cell Biol, 13 (6): 3683-97.

[11] Park BL, Kim LH, Cheong HS, Cho HY, Kim EM, Shin HD, Kim YS, Lee C. (2004). Identification of variants in cyclin D1 (CCND1) and B-cell CLL/lymphoma 2 (BCL-2). J Hum Genet, 49 (8): 449-54.

[12] Kidd LR, Coulibaly A, Templeton TM, Chen W, Long LO, Mason T, Bonilla C, Akereyeni F, Freeman V, Isaacs W, Ahaghotu C, Kittles RA. (2006). Germline BCL-2 sequence variants and inherited predisposition to prostate cacner. Prostate Cancer Prostatic Dis, 9 (3): 284-92.

[13] Miyashita T, Krajewski S, Krajewska M, Wang HG, Lin HK, Liebermann DA, Hoffman B, Reed JC. (1994a). Tumor suppressor p53 is a regulator of BCL-2 and BAX gene expression in vitro and in vivo. Oncogene, 9 (6): 1799-805.

[14] Miyashita T, Harigai M, Hanada M, Reed JC. (1994b). Identification of a p53-dependent negative response element in the BCL-2 gene. Cancer Res, 54 (12): 3131-5.

[15] Ke X, Collins A, Ye S. (2001). PIRA PCR designer for restriction analysis of single nucleotide polymorphisms. Bioinformatics 17 : 838-9.

[16] Manju L, George PS, Mathew A. (2009). Urinary bladder cancer risk among motor vehicle drivers: a meta-analysis of the evidence, 1977-2008. Asian Pac J Cancer Prev, 10 (2): 287-94.

[17] Cassidy A, Wang W, Wu X, Lin J. (2009). Risk of urinary bladder cancer: a case-control analysis of industry and occupation. BMC Cancer, 9: 443

[18] Samanic CM, Kogevinas M, Silverman DT, Tardon A, Serra C, Malats N, Real FX, Carrato A, Garcia-Closas R, Sala M, Lloreta J, Rothman N, Dosemeci M. (2008). Occupation and bladder cancer in a hospital-based case-control study in Spain. Occup Environ Med, 65 (5): 347-53.

[19] Atug F, Turkeri L, Ozyurek M, Akdas A. (1998). BCL-2 and p53 overexpression as associated risk factors in transitional cell carcinoma of the bladder. Int Urol Nephrol, 30 (4): 455-61.

[20] Asci R, Yildiz L, Sarikaya S, Buyukalpelli R, Yilmaz AF, Kandemir B. (2001). P53 and BCL-2 overexpression as associated risk factors in patients 40 years old or less with transitional cell carcinoma of the bladder. Urol Int, 67 (1): $34-40$.

[21] Kirsh EJ, Baunoch DA, Stadler WM. (1998). Expression of BCL-2 and BCL-X in bladder cancer. J Urol, 159 (4): 1348-53.

[22] Zinkel S, Gross A, Yang E. (2006). BCL2 family in DNA damage and cell cycle control. Cell Death Differ, 13 (8): 1351-9.

[23] Hanson CJ, Bootman MD, Distelhorst CW, Maraldi T, Roderick HL. (2008). The cellular concentration of BCL-2 determines its pro- or anti-apoptotic effect. Cell Calcium, 44 (3): 243-58.

[24] Kumar P, Ning Y, Polverini PJ. (2008). Endothelial cells expressing BCL-2 promotes tumor metastasis by enhancing tumor angiogenesis, blood vessel leakiness and tumor invasion. Lab Invest, 88 (7): 740-9.

[25] Keshgegian AA, Johnston E, Cnaan A. (1998). BCL-2 oncoprotein positivity and high MIB-1 (Ki-67) proliferative rate are independent predictive markers for recurrence in prostate carcinoma. Am J Clin Pathol, 110 (4): 443-9.

[26] Faderl S, Keating MJ, Do KA, Liang SY, Kantarjian HM, O’Brien S, Garcia-Manero G, Manshouri T, Albitar M. (2002). Expression profile of 11 proteins and their prognostic significance in patients with chronic lymphocytic leukemia (CLL). Leukemia, 16 (6): $1045-52$.

[27] Ofner D, Riehemann K, Maier H, Riedmann B, Nehoda H, Totsch M, Bocker W, Jasani B, Schmid KW. (1995). Immunohistochemically detectable BCL-2 expression in colorectal carcinoma: correlation with tumor stage and patient survival. $\mathrm{Br}$ J Cancer, 72 (4): 981-5.

[28] Zhang GJ, Kimijima I, Tsuchiya A, Abe R. (1998). The role of BCL-2 expression in breast carcinomas (Review). Oncol Rep, 5 (5): 1211-6.

[29] Wilson GD, Grover R, Richman PI, Daley FM, Saunders MI, Dische S. (1996). BCL-2 expression correlates with favorable outcome in head and neck cancer treated by accelerated radiotherapy. Anticancer Res, 16 (4C): 2403-8.

[30] Homma A, Furuta Y, Oridate N, Nakano Y, Kohashi G, Yagi K, Nagahashi T, Yagi K, Nagahashi T, Fukuda S, Inoue K, Inuyama Y. (1999). Prognostic significance of clinical parameters and biological markers in patients with squamous cell carcinoma of the head and neck treated with concurrent chemoradiotherapy. Clin Cancer Res, 5 (4): 801-6.

[31] Pena JC, Thompson CB, Recant W, Vokes EE, Rudin CM. (1999). BCL-xL and BCL-2 expression in squamous cell carcinoma of the head and neck. Cancer, 85 (1): 164-70.

[32] Stoll C, Baretton G, Ahrens C, Lohrs U. (2000). Prognostic significance of apoptosis and associated factors in oral squamous cell carcinoma. Virchows Arch, 436 (2): 102-8. 
[33] Hague A, Moorghen M, Hicks D, Chapman M, Paraskeva C. (1994). BCL-2 expression in human colorectal adenomas and carcinomas. Oncogene, 9 (11): 3367-70.

[34] Bronner MP, Culin C, Reed JC, Furth EE. (1995). The BCL2 proto-oncogene and the gastrointestinal epithelial tumor progression model. Am J Pathol, 146 (1): 20-6.

[35] Sinicrope FA, Ruan SB, Cleary KR, Stephens LC, Lee JJ, Levin B. (1995). Bcl-2 and p53 oncoprotein expression during colorectal tumorigenesis. Cancer Res, 55 (2): 237-41

[36] Hanada M, Delia D, Aiello A, Stadtmauer E, Reed JC. (1993). BCL-2 gene hypomethylation and high-level expression in B-cell chronic lymphocytic leukemia. Blood, 82 (6): 1820-8.

[37] Pepper C, Hoy T, Bentley DP. (1997). BCL-2/BAX ratios in chronic lymphocytic leukemia and their correlation with in vitro apoptosis and clinical resistance. Br J Cancer, 76 (7): 935-8.

[38] Saxena A, Viswanathan S, Moshynska O, Tandon P, Sankaran K, Sheridan DP. (2004). Mcl-1 and Bcl-2/Bax ratio are associated with treatment response but not with Rai stage in B-cell chronic lymphocytic leukemia. Am J Hematol, 75 (1): 22 -33.

[39] Thomas A, El Rouby S, Reed JC, Krajewski S, Silber R, Potmesil M, Newcomb EW. (1996). Drug-induced apoptosis in B-cell chronic lymphocytic leukemia: relationship between p53 gene mutation and bcl-2/bax proteins in drug resistance. Oncogene, 12 (5): 1055-62.

[40] Cooke PW, James ND, Ganesan R, Burton A, Young LS, Wallace DM. (2000). Bcl-2 expression identifies patients with advanced bladder cancer treated by radiotherapy who benefit from neoadjuvant chemotherapy. BJU Int, 85 (7): 829-35.

[41] Hellemans P, van Dam PA, Weyer J, van Oosterom AT, Buytaert P, Van Marck E. (1995). Prognostic value of BCL2 expression in invasive breast cancer. Br J Cancer, 72 (2): 354-60.

[42] Krajewska M, Krajewski S, Epstein JI, Shabaik A, Sauvageot J, Song K, Kitada S, Reed JC. (1996). Immunohistochemical analysis of BCL2, BAX, bcl-X and mcl-1 expression in prostate cancers. Am J Pathol, 148 (5): 1567-76.

[43] Gallo O, Chiarelli I, Boddi V, Bocciolini C, Bruschini L, Porfirio B. (1999). Cumulative prognostic value of p53 mutations and BCL2 protein expression in head-and-neck cancer treated by radiotherapy. Int J Cancer, 84 (6): 573-9.

[44] Harima Y, Harima K, Shikata N, Oka A, Ohnishi T, Tanaka Y. (1998). BAX and Bcl-2 expressions predict response to radiotherapy in human cervical cancer. J Cancer Res Clin Oncol, 124 (9): 503-10.

[45] Apakama I, Robinson MC, Walter NM, Charlton RG, Royds JA, Fuller CE, Neal DE, Hamdy FC. (1996). Bcl-2 overexpression combined with $\mathrm{p} 53$ protein accumulation correlates with hormone-refractory prostate cancer. Br J Cancer, 74 (8): $1258-62$.

[46] King ED, Matteson J, Jacobs SC, Kyprianou N. (1996). Incidence of apoptosis, cell proliferation and BCL2 expression in transitional cell carcinoma of the bladder: association with tumor progression. J Urol, 155 (1): 316-20.

[47] Shiina H, Igawa M, Urakami S, Honda S, Shirakawa H, Ishibe T. (1996). Immunohistochemical analysis of BCL2 expression in transitional cell carcinoma of the bladder. J Clin Pathol, 49 (5): 395-9.

[48] Pollack A, Wu CS, Czerniak B, Zagars GK, Benedict WF, McDonnell TJ. (1997). Abnormal BCL2 and pRb expression are independent correlates of radiation response in muscle-invasive bladder cancer. Clin Cancer Res, 3 (10): 1823-9.

[49] Kong G, Shin KY, Oh YH, Lee JJ, Park HY, Woo YN, Lee JD. (1998). Bcl-2 and p53 expressions in invasive bladder cancers. Acta Oncol, 37 (7-8): 715-20.

[50] Ye D, Li H, Qian S, Sun Y, Zheng J, Ma Y. (1998). BCL2/BAX expression and p53 gene status in human bladder cancer: relationship to early recurrence with intravesical chemotherapy after resection. J Urol, 160 (6): 2025-8.

[51] Chen K, Hu Z, Wang, L-E, Sturgis EM, El-Naggar AK, Zhang W, Wei Q. (2007). Single-nucleotide polymorphisms at the TP53binding or responsive promoter regions of BAX and BCL2 genes and risk of squamous cell carcinoma of the head and neck. Carcinogenesis, 28 (9): 2008-12.

[52] Nuckel H, Frey UH, Bau M, Sellmann L, Stanelle J, Durig J, Jockel KH, Duhrsen U, Siffert W. (2007). Association of a novel regulatory polymorphism $(-938 \mathrm{C}>\mathrm{A})$ in the BCL2 gene promoter with disease progression and survival in chronic lymphocytic leukemia. Blood, 109 (1): 290-7.

[53] Majid A, Tsoulakis O, Walewska R, Gesk S, Siebert R, Kennedy DB, Dyer MJ. (2008). BCL2 expression in chronic lymphocytic leukemia: lack of association with the BCL2 -938A>C promoter single nucleotide polymorphism. Blood, 111 (2): 874-7.

[54] Lehnerdt GF, Franz P, Bankfalvi A, Grehl S, Kelava A, Nuckel H, Lang S, Schmid KW, Siffert W, Bachmann HS. (2009). The regulatory BCL-2 promoter polymorphism $(-938 \mathrm{C}>\mathrm{A})$ is associated with relapse and survival of patients with oropharyngeal squamous cell carcinoma. Ann Oncol, 20 (6): 1094-9.

[55] Hu Z, Li C, Chen K, Wang L-E, Sturgis EM, Spitz MR, Wei Q. (2008). Single nucleotide polymorphisms in selected apoptotic genes and BPDE-induced apoptotic capacity in apparently normal primary lymphocytes: A genotype-phenotype correlation analysis. J Cancer Epidemiol, 2008: pp. 8.

[56] Teni T, Pawar S, Sanghvi V, Saranath D. (2002). Expression of BCL-2 and BAX in chewing tobacco-induced oral cancers and oral lesions from India. Pathol Oncol Res, 8 (2): 109-14.

[57] Mai H, May WS, Gao F, Jin Z, Deng X. (2003). A functional role for nicotine in BCL-2 phosphorylation and suppression of apoptosis. J Biol Chem, 278 (3): 1886-91.

[58] Gallo O, Bianchi S, Porfirio B. (1995). BCL-2 over-expression and smoking history in head-and-neck cancer. J Natl Cancer Inst, 87 (13): 1024-5.

[59] Dimmeler S, Breitschopf K, Haendeler J, Zeiher AM. (1999). Dephosphorylation targets BCL-2 for ubiquitin-dependent degradation: a link between the apoptosome and the proteasome pathway. J Exp Med, 189 (11): 1815-22.

[60] Deng X, Gao F, Mai H, May WS. (2001). Multiple site BCL-2 phosphorylation in the flexible loop domain (FLP) unexpectedly enhances anti-apoptotic function (abstract). Blood, 98: 796a.

[61] Deng X, Ruvolo P, Carr BK, May WS. (2000). Survival function of ERK1/2 as IL-3-activated, staurosporine-resistant BCL-2 kinases. Proc Natl Acad Sci USA, 97 (4): 1578-83.

[62] Wei MC, Zong WX, Cheng EH, Lindsten T, Panoutsakopoulou V, Ross AJ, Roth KA, MacGregor GR, Thompson CB, Korsmeyer SJ. (2001). Proapoptotic BAX and BAK: a requisite gateway to mitochondrial dysfunction and death. Science, 292 (5517): 727-30.

[63] Oltvai ZN, Milliman CL, Korsmeyer SJ. (1993). Bcl-2 heterodimerizes in vivo with a conserved homolog, Bax, that accelerates programmed cell death. Cell, 74 (4): 609-19.

[64] Kumar R, Verma V, Jain A, Jain RK, Maikhuri JP, Gupta G. (2010). Synergistic chemoprotective mechanisms of dietary phytoestrogens in a select combination against prostate cancer. J Nutr Biochem, 22 (8): 723-31.

[65] Chang J, Hsu Y, Kuo P, Kuo Y, Chiang L, Lin C. (2005). Increase of BAX/BCL-xL ratio and arrest of cell cycle by luteolin in immortalized human hepatoma cell line. Life Sci, 76 (16): 1883-93.

[66] Vijayababu MR, Kanagaraj P, Arunkumar A, Ilangovan R, Aruldhas MM, Arunakaran J. (2005). Quercetin-induced growth inhibition and cell death in prostatic carcinoma cells (PC-3) are associated with increase in p21 and hypophosphorylated retinoblastoma proteins expression. J Cancer Res Clin Oncol, 131 (11): 765-71. 
[67] Fimognari C, Nusse M, Berti F, Iori R, Cantelli-Forti G, Hrelia P. (2003). Sulforaphane modulates cell cycle and apoptosis in transformed and non-transformed human T lymphocytes. Ann NY Acad Sci, 1010: 393-8.

[68] Karmakar S, Weinberg MS, Banik NL, Patel SJ, Ray SK. (2006). Activation of multiple molecular mechanisms for apoptosis in human malignant glioblastoma T98G and U87MG cells treated with sulforaphane. Neuroscience, 141 (3): 1265-80.

[69] Xu C, Shen G, Yuan X, Kim JH, Gopalkrishnan A, Keum YS, Nair S, Kong AN. (2006). ERK and JNK signaling pathways are involved in the regulation of activator protein 1 and cell death elicited by three isothiocyanates in human prostate cancer PC-3 cells. Carcinogenesis, 27 (3): 437-45.

[70] Lee JW, Cho MK. (2008). Phenethyl isothiocyanate induced apoptosis via down regulation of BCL-2/XIAP and triggering of the mitochondrial pathway in MCF-7 cells. Arch Pharm Res, 31 (12): 1604-12.

Table I. Conditions of genotyping assays for the $B C L-2938 C / A$ polymorphism

\begin{tabular}{|c|c|c|c|c|}
\hline $\begin{array}{c}\text { Single Nucleotide } \\
\text { Polymorphism }\end{array}$ & Primers & $\begin{array}{c}\text { PCR } \\
\text { product }\end{array}$ & Enzyme & $\begin{array}{l}\text { Gel band } \\
\text { pattern }\end{array}$ \\
\hline \multirow[t]{2}{*}{$\begin{array}{c}B C L-2938 \mathrm{C} / \mathrm{A} \\
\text { (Hu et al., 2008) }\end{array}$} & 5'-TCCTGCCTTCATTTATCCAGCA-3' & \multirow[t]{2}{*}{125 bp } & \multirow{2}{*}{$\begin{array}{c}\text { NlaIII } \\
(5 \mathrm{U}, 5 \mathrm{hr} \text {, } \\
\left.37^{\circ} \mathrm{C}\right)\end{array}$} & $\begin{array}{l}C \text { allele: } 106 \text { bp, } \\
19 \text { bp }\end{array}$ \\
\hline & 5'-CCAGGAGAGAGACAGGGGA $\underline{C A}-3$ ' & & & $\begin{array}{l}A \text { allele: } 125 \text { bp } \\
\text { (Figure 1) }\end{array}$ \\
\hline
\end{tabular}

Table II. Distribution of $B C L-2938$ C/A genotype frequencies among cases and controls

\begin{tabular}{|c|c|c|c|c|}
\hline Genotype & $\begin{array}{c}\text { Cases }(\%) \\
(n=270)\end{array}$ & $\begin{array}{c}\text { Controls }(\%) \\
(n=252)\end{array}$ & OR (95\% CI) & $p$-value \\
\hline $\mathrm{CC}$ & $173(64.07)$ & $155(61.51)$ & 1 (Ref.) & -- \\
\hline $\mathrm{CA}$ & $75(27.78)$ & $66(26.19)$ & $1.02(0.67-1.54)$ & 0.929 \\
\hline $\mathrm{CA}+\mathrm{AA}$ & $97(35.93)$ & $97(38.49)$ & $0.90(0.62-1.30)$ & 0.544 \\
\hline
\end{tabular}

* Significant $p$-values are in bold $(p<0.05)$; OR, Odds Ratio; CI, Confidence Interval

Table III. Stratification analysis of the $B C L-2938 \mathrm{C} / \mathrm{A}$ genotype frequencies in cases and controls

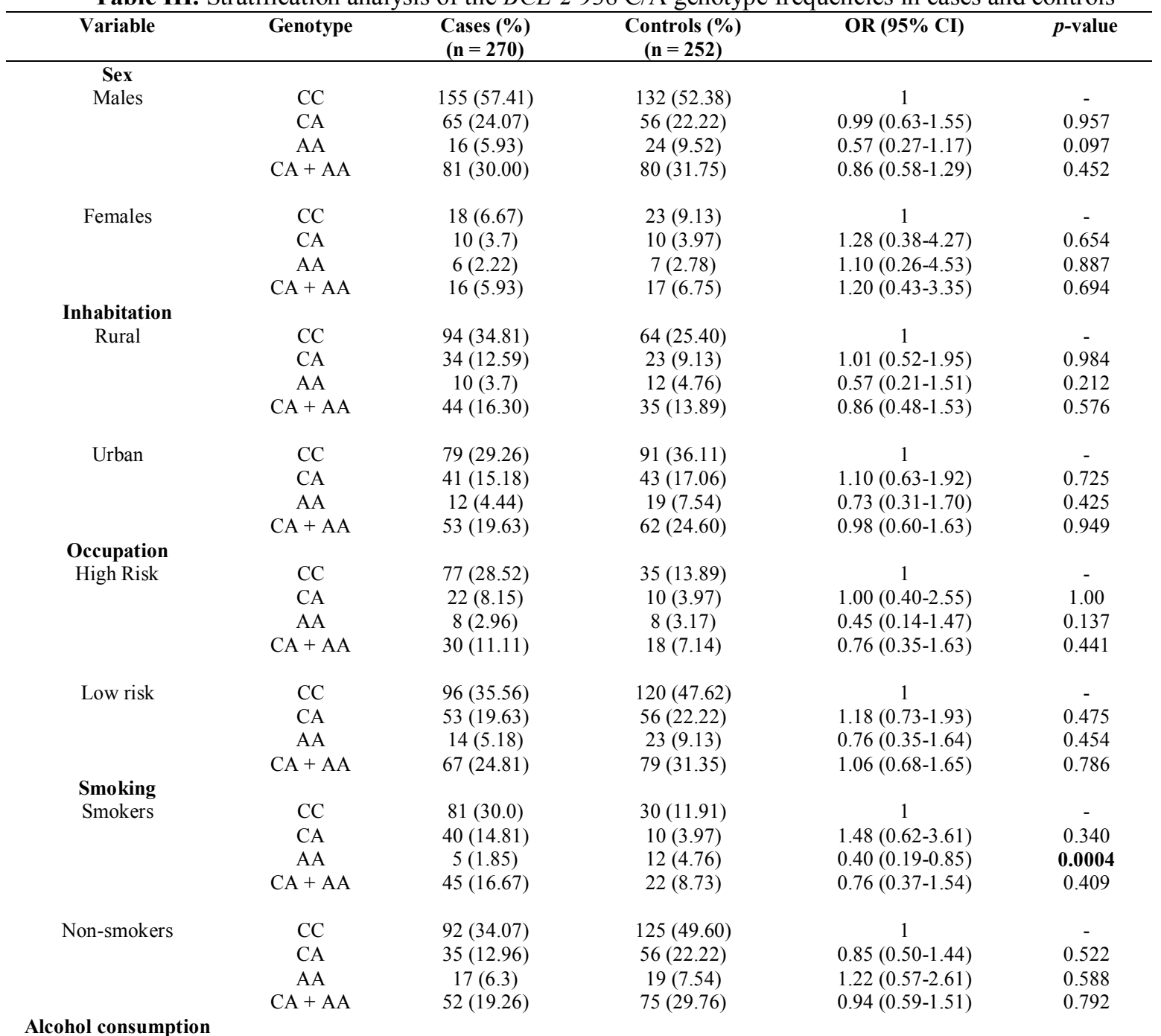


A single nucleotide polymorphism in BCL-2 gene determines the risk of urinary bladder cancer

\begin{tabular}{|c|c|c|c|c|c|}
\hline \multirow{4}{*}{ Alcoholic } & $\mathrm{CC}$ & $70(25.93)$ & $51(20.24)$ & 1 & - \\
\hline & CA & $29(10.74)$ & $21(8.33)$ & $1.01(0.49-2.07)$ & 0.986 \\
\hline & $\mathrm{AA}$ & $14(5.18)$ & $13(5.16)$ & $0.78(0.31-1.96)$ & 0.569 \\
\hline & $\mathrm{CA}+\mathrm{AA}$ & $43(15.93)$ & $34(13.49)$ & $0.92(0.50-1.71)$ & 0.781 \\
\hline \multirow[t]{4}{*}{ Non-alcoholic } & $\mathrm{CC}$ & $103(38.15)$ & $104(41.27)$ & 1 & - \\
\hline & $\mathrm{CA}$ & $46(17.04)$ & $45(17.86)$ & $1.03(0.61-1.74)$ & 0.900 \\
\hline & AA & $8(2.96)$ & $18(7.14)$ & $0.45(0.17-1.15)$ & 0.068 \\
\hline & $\mathrm{CA}+\mathrm{AA}$ & $54(20.00)$ & $63(25.00)$ & $0.87(0.54-1.40)$ & 0.533 \\
\hline \multicolumn{6}{|l|}{ Eating habits } \\
\hline \multirow[t]{4}{*}{ Vegetarian } & $\mathrm{CC}$ & $92(34.07)$ & $81(32.14)$ & 1 & - \\
\hline & $\mathrm{CA}$ & $42(15.56)$ & $38(15.08)$ & $0.97(0.55-1.71)$ & 0.920 \\
\hline & $\mathrm{AA}$ & $7(2.59)$ & $16(6.35)$ & $0.39(0.14-1.06)$ & 0.0403 \\
\hline & $\mathrm{CA}+\mathrm{AA}$ & $49(18.15)$ & $54(21.43)$ & $0.80(0.48-1.34)$ & 0.367 \\
\hline \multirow[t]{4}{*}{ Non-vegetarian } & $\mathrm{CC}$ & $81(30.0)$ & $74(29.36)$ & 1 & - \\
\hline & $\mathrm{CA}$ & $33(12.22)$ & $28(11.11)$ & $1.08(0.57-2.04)$ & 0.807 \\
\hline & AA & $15(5.56)$ & $15(5.95)$ & $0.91(0.39-2.14)$ & 0.821 \\
\hline & $\mathrm{CA}+\mathrm{AA}$ & $48(17.78)$ & $43(17.06)$ & $1.02(0.59-1.77)$ & 0.941 \\
\hline
\end{tabular}

* Significant $p$-values are in bold $(p<0.05)$; OR, Odds Ratio; CI, Confidence Interval

Table IV. Distribution of the $B C L-2938 \mathrm{C} / \mathrm{A}$ genotypes according to stages and histo-pathological grades

\begin{tabular}{|c|c|c|c|c|}
\hline STAGES & Genotype & $\begin{array}{c}\text { Cases }(\%) \\
(n=270)\end{array}$ & OR (95\% CI) & $p$-value \\
\hline \multirow[t]{4}{*}{ Superficial } & $\mathrm{CC}$ & $133(49.26)$ & 1 & - \\
\hline & $\mathrm{CA}$ & $60(22.22)$ & $1.06(0.68-1.65)$ & 0.787 \\
\hline & AA & $19(7.04)$ & $0.71(0.37-1.38)$ & 0.283 \\
\hline & $\mathrm{CA}+\mathrm{AA}$ & $79(29.26)$ & $0.95(0.64-1.41)$ & 0.786 \\
\hline \multirow[t]{4}{*}{ Muscle-invasive } & $\mathrm{CC}$ & $40(14.81)$ & 1 & - \\
\hline & $\mathrm{CA}$ & $15(5.56)$ & $0.88(0.43-1.78)$ & 0.706 \\
\hline & AA & $3(1.11)$ & $0.43(0.14-1.31)$ & 0.107 \\
\hline & $\mathrm{CA}+\mathrm{AA}$ & $18(6.67)$ & $0.72(0.37-1.38)$ & 0.289 \\
\hline \multicolumn{5}{|l|}{ GRADES } \\
\hline \multirow[t]{4}{*}{ G1 } & $\mathrm{CC}$ & $50(18.52)$ & 1 & - \\
\hline & $\mathrm{CA}$ & $20(7.41)$ & $0.94(0.50-1.77)$ & 0.836 \\
\hline & $\mathrm{AA}$ & $4(1.48)$ & $0.47(0.18-1.22)$ & 0.090 \\
\hline & $\mathrm{CA}+\mathrm{AA}$ & $24(8.89)$ & $0.77(0.43-1.37)$ & 0.343 \\
\hline \multirow[t]{4}{*}{ G2 } & $\mathrm{CC}$ & $96(35.56)$ & 1 & - \\
\hline & CA & $38(14.07)$ & $0.96(0.56-1.53)$ & 0.762 \\
\hline & $\mathrm{AA}$ & $17(6.3)$ & $0.93(0.61-1.40)$ & 0.711 \\
\hline & $\mathrm{CA}+\mathrm{AA}$ & $55(20.37)$ & $0.92(0.59-1.42)$ & 0.678 \\
\hline \multirow[t]{4}{*}{ G3 } & $\mathrm{CC}$ & $27(10.0)$ & 1 & - \\
\hline & CA & $17(6.3)$ & $1.48(0.72-3.04)$ & 0.252 \\
\hline & AA & $1(0.37)$ & $0.21(0.03-1.50)$ & 0.088 \\
\hline & $\mathrm{CA}+\mathrm{AA}$ & $18(6.67)$ & $1.07(0.53-2.13)$ & 0.848 \\
\hline
\end{tabular}

* Significant $p$-values are in bold $(p<0.05)$; OR, Odds Ratio; CI, Confidence Interval

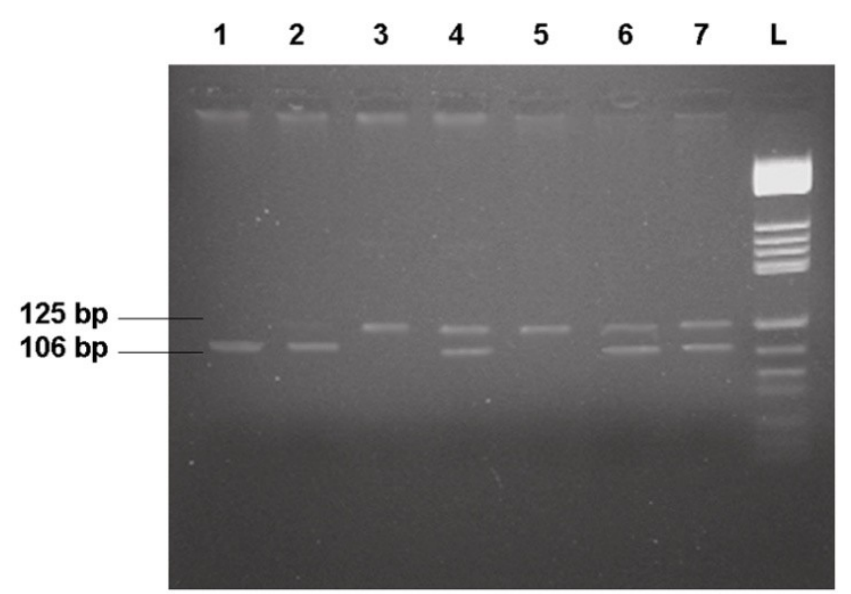

Figure I: A representative 4\% gel showing RFLP product of $B C L-2$ after digestion with NlaIII: lanes $1,2=\mathrm{C} / \mathrm{C}$ (106 bp); lanes 3, $5=\mathrm{A} / \mathrm{A}$ (125 bp); lanes 4, 6, $7=\mathrm{C} / \mathrm{A}$ (125 and $106 \mathrm{bp})$; and lane L=pBR322 DNA/HaeIII

Digest. Note that the 19 bp fragment for the $B C L-2$ assay is not resolved on the gels used. 